\title{
NACIONALNE RELIGIJE I NJIHOVI DEMONI: OD BOGA DO POLEMOSA ${ }^{1}$
}

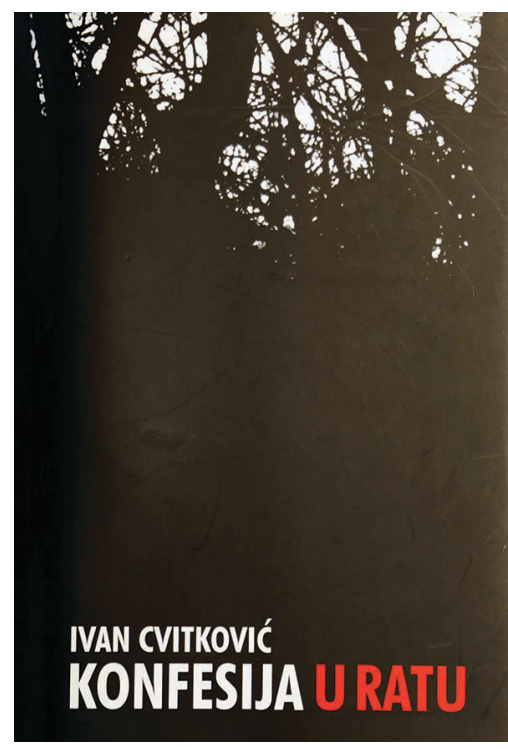
pored toga za mene vrijedno svjedočanstvo o Bosni i Hercegovini koju još uvijek doživljavam kao moju zemlju ili dio zemlje koja je na neki način moja. U tom pogledu vaša knjiga mi je pružila bolji uvid u neke izvorne stavove bosanskih konfesionalnih i političkih aktera za koje nisam inače znao. Inače bilo mi je drago vidjeti da ste ostali vjerni svojim načelnim stajalištima koja su veoma bliska mojima. Ono u čemu bih se ponešto razlikovao od vas tiče se mojih nastojanja da se dominantne političke strategije $\mathrm{u}$ BiH odrede kao nacionalističke te da se ciljeve tih strategija, iz njihovih stavova o izboru legitimnih sredstava društvenog djelovanja da bi se ti ciljevi realizirali, i iz povijesne artikulacije bosanskog prostora i bosanske zbilje u koju se te političke ciljeve htjelo po svaku cijenu implementirati. Druga moguća točka razlikovanja mi se čini da leži u mom nešto kritičnijem odnosu prema službenim izjavama i deklaracijama crkvenih vrhova. Ja držim da je moguće spojiti mirotvornu retoriku i pribavljanje religijskog legitimiteta politikama koje svoje ciljeve ne mogu pod datim okolnostima ostvariti nego nasiljem, a to znači i ratom; isto tako držim da je moguće spojiti određene osude političkog djelovanja in abstracto i praktičnim prilagođavanjem njima in concreto. Za neke takve izjave držim da su date daleko više zbog umirenja vlastite savjesti nego zbog izravnog utjecaja na tog zbivanja.

Hvala još jednom. Uz srdačan kolegijalni pozdrav.

Vrcan" 
loška kriza pojavljuje kao jedna od ultimativnih figura kraja dvadesetog i početka dvadeset prvog stoljeća. U znanosti se kriza vrijednosti manifestira tako što se značajan broj znanstvenika uopće ne bavi znanošću, znajući da im je za društveno i profesionalno napredovanje dovoljna ideološka, najčešće desna etnoreligijska i stranačka pravovaljanost. Tako se kao rezultat ideologizirane znanstvene svijesti pojavljuju s jedne strane nerad, a s druge knjige koje se, iz razloga jaransko-provincijalnog i etničkog altruizma kao kolektiviziranog egoizma objavljuju, mada je jedini smisleni razlog njihovog pojavljivanja to što papir svašta trpi i ne može se oduprijeti besmislu.

Knjiga Konfesija u ratu Ivana Cvitkovića s onu je stranu navedenog znanstvenog minimalizma ili protuznanstvenog maksimalizma. Uronjena u vrijeme, autorska odiseja našeg cijenjenog sociologa religije potraga je za motivima koji onostrano spuštaju u ovostrano, i to u onom predjelu svijeta koji se zove Bosna i u onom vremenu svijeta koji se zove rat. Ivan Cvitković, dakle, istražuje vezu između religijskog i rata, između Boga i Polemosa.

Kroz različite primjere relacijskog i korelacijskog odnosa objavljenih religija sa ratom, Cvitković, upotrebljivim sociološkim instrumentarijem, istražuje konkretne religijske i političke aplikacije objavljenih Dogmi koje su i na negativan i na pozitivan način obilježile rat protiv Bosne i Hercegovine.

Možda je ocjena prestroga, ali moje čitanje Cvitkovićevog čitanja konfesija u bosanskohercegovačkom ratu podložno je uvjerenju kako su se u sferi karitativnog religije, odnosno religijske institucije i njihovi socijalni derivati, objavljivali kao Etos i Eros, a u zoni političkog kao Tanatos. Tu moju ocjenu tek neznatno relativiziraju različita saopćenja vrhovnih poglavara i upravljačkih institucija religijskih zajednica, koja (ta saopćenja), iako ekumenska, rijetko su kada otišla dalje od načelnog stava koji naprosto u vremenu rata nije dovoljan, naročito što upotreba zla u ime religijskog nije bila načelna, već konkretna, kao genocid, urbicid, memoricid... Naravno, mi možemo kreiranje i funkcioniranje zla u ime religijskog opravdano tretirati kao pseudoreligijsko, no ostaje problem za teološka, filozofska i sociološka istraživanja pokušati odgovoriti na pitanje - ako se nešto može zloupotrijebiti, je li dovoljan argument - kako se sve može zloupotrijebiti? Naročito kad u tu zloupotrebu spada i upotreba Zla. ${ }^{2}$

\footnotetext{
${ }^{2}$ Princip da se sve može zloupotrijebiti u svoju odbranu i htijući i nehtijući zaziva đavola, odnosno on se pojavljuje kao opravdanje svakovrsnih nesolidnih radnji. U Stenogramu demonove metafizičke konferencije za štampu održane u Varšavi 20. decembra 1963. đavo se, po Leszeku Kolakowskom, ovako predstavio: "Kad je zlo u pravu - kad nastaje iz ljubavne požude, iz straha, iz želje za bogatstvom, iz oholosti, čak iz taštine ili iz želje za osvetom - moje učešće u njemu je neveliko. Zlo je opravdano, racionalno, hoće jedino da postigne cilj za kojim bi poseglo i bez njega, kad bi bez njega bio dostižan. Sama strast, sama požuda
} 
Profesor Cvitković je pasionirani sociolog-istraživač, pa je znalačkom upotrebom velikog broja različitih izvora, kako teoloških, tako i socioloških, fillozofskih, političkih i publicističkih, osnažio svoje temeljno uvjerenje sociologa lijeve orijentacije da je "neophodno razvijati jednakopravnost, toleranciju, njegovati i očuvati različitosti” (str. 191) u Bosni i Hercegovini, jer je to smislen, razuman i razložan način da sve bosanske konfesije efektuiraju svoj nalog Dobra u konkretnoj praksi jedne složene zajednice i izbjegnu zamku monoetničke religijskonacionalističke zavodljivosti koju ne zanima Drugi, ${ }^{3}$ onaj Drugi koji je i u Levinasovom (Apsolutno Drugo, Željeno Drugo, Drugi kao sugovornik) i u Buberovom smislu Ja. Jer, "osnovna riječ Ja-Ti zasniva svijet odnosa".

Ivan Cvitković će kao sociolog religije, oslobođen maligne potrebe da se bude sluga političkog, utvrditi na osnovu meritornih izvora da se u regionalnom i bosanskohercegovačkom ratu protiv Bosne i Hercegovine konfesije nisu baš pretrgle da uspostave odnos Ja-Ti koji bi prešao artificijelne granice bosanskih svjetova. Zato se autor i pita: “... jesu li se univerzalne religije u Bosni i Hercegovini pretvorile u religije konflikta?” (str. 185) Ali te granice i jesu izmaštane i praktično konkretizirane da bi se poništio transcendentalni sinkretizam i uspostavile tri autonomne zone etnoreligijskih zajednica na otužnom zovu Huntingtonove redukcionističke paradigme. No, Bosna je, u jednom transpovijesnom smislu, jača od svojih unutrašnjih protivnika - a oni to jesu čak i kada ne znaju - koji su uspostavili vrlo profane veze između

ili strah ne potiču od đavola, a zlo koje služi njihovom zadovoljenju služi samo kao nužno oruđe" (Kolakowski 1990: 138) ljudima i njihovim institucijama (pa tako i vjerskim) da upotrebom zla sačuvaju svijet od zla koje tretiraju kao činjeničnu naprslinu "unutar esencijalnog, od strane dobra, uređenog svijeta" (Kolakowski 1990: 139). Na taj način, pretpostavljajući Dobro kao Apsolut (a to Dobro je uvijek parcijalno jer je Etničko Dobro, Dobro Moje Vjere, Stranačko Dobro...), čine Zlo. Eklatantan primjer je Srpska pravoslavna crkva, odnosno ponašanje njenog svetopolitičkog vrha (ova sintagma nije besmislica) tokom rata protiv Bosne i Hercegovine. Simbioza političkog liderstva (Radovan Karadžić), vojnog (Ratko Mladić) i duhovnog (patrijarh Pavle) nije bila eksces, već očigledna notornost. Svetopolitički vrh SPC-a upotrebom zla (npr. davanjem duhovne podrške za ubijanje muslimana) kao "nužnim oruđem" pokušava sačuvati svijet Dobra (Srpstvo i Pravoslavlje) od muslimanstva, koje se u hijerarhijskom vrhu Crkve doživljava kao konkretna apstrakcija zla i činjenična naprslina u tkivu svijeta kao Pravoslavnog Dobra. Tim esencijalističkim pristupom, čak toliko esencijalističkim kao da je iz njega izvađen drugi korijen, pa se ne može dodatno smisleno esencijalizirati, Samoproglašeno Dobro proizvodi zlo na čijem kraju je sama esencija zla: genocid. 3 “Pluralizam podrazumijeva da se ne može negirati, uništiti ili otjerati drugi iz Bosne i Hercegovine. Bilo bi katastrofalno po Bosnu i Hercegovinu ako bi njezine nacije i konfesije u otvorenom društvu vidjele neprijatelja kojemu se treba suprotstaviti. Naravno, religijski pluralizam (pokazao je to i rat) ne znači automatski i otvorenost prema religijskoj različitosti." (Cvitković: 185) 
Islamske zajednice i SDA, Katoličke crkve i HDZ-a, Pravoslavne crkve i SDS-a. Ivo Banac takve "simbiotičke klopke" naziva "sekularizam Crkve", a aktivna je i analitički upotrebljiva i sintagma Gaje Sekulića o opasnostima "sekularizirane teologije". No, iako Bosna pronalazi snage da je bude, to još uvijek ne znači da ne može biti ubijena, jer veliki broj interpretiranih izvora $\mathrm{u}$ ovoj knjizi potvrđuje da su institucionalizirane, instrumentalizirane, posvjetovljene religijske zajednice (kao uostalom i teologizirane političke stranke) više radile protiv Bosne, nego za Bosnu. Ipak, nikada ne smijemo zaboraviti one mantije i one ahmedije kojima Bog zbog njihove istinske zauzetosti za maloga čovjeka sprema rajske darove. Ti ljudi vjere nisu činili dobročinstvo $\mathrm{i}$ milosrđe prema svima (dakle, prema nikome), već prema konkretnim, malim ljudima.

Za mene je jedna od ključnih vrijednosti Cvitkovićevog rada pozivanje na drugog, na druge izvore, kojima je autor u velikoj mjeri prepustio da se sami konstituiraju, ne samo kao izvor već i kao poruka. Istovremeno, vrijedi uputiti zamjerku autoru što je prepuštajući izvore da sami sebe govore u određenim dionicama knjige propustio da "na volej dočeka" one izjave konfesionalnih vjerodostojnika koje su bliže "udjelu đavla" nego udjelu anđela. To ne umanjuje sociologijsku bistrinu ove knjige, čak joj daje i jedan publicistički šarm, no u strogom metodologijskom smislu jedna "unutrašnja svađa" s iznijetim činjenicama dodatno bi osnažila i pročistila tekst te ga učinila zgusnutijim. A nema ničega izvan Teksta, pa svako ko bude imao prigovora na Cvitkovićev značajan sociološkoreligijski uradak, moraće to saopćiti tekstom, svojim tekstom, a ne ideologijskim konstrukcijama i apriornim predstavama. No, opet imam razumijevanja za Cvitkovićev postupak, jer, ovo slutim intuitivno, autoru kao da je jednostavno bilo žao rasteretiti rukopis izbacivanjem određenih podataka i fakata, naročito imajući u vidu da mi u BiH ovakav sociološki registar konfesija u ratu uopće nemamo. Tu ulogu je preuzela teologija i ovom knjigom Cvitković poručuje dinamičnoj teološkoj izdavačkoj djelatnosti da je sociologija religije u BiH još uvijek živa, zahvaljujući, između ostaloga, i autoru knjige Konfesija u ratu.

Ovaj rukopis otvara se, upotrijebiću jednu akustičnu paralelu, kao muzička kutija. U prvom dijelu knjige autor reda more činjenica, podataka, informacija, čitalac, neko više, a neko manje, biće zadovoljan libretom, neko će ustvrditi da je prva polovina knjige predominantno upućena na izvore koji se odnose na islam i Islamsku zajednicu u Bosni i iz toga izvući negativne zaključke, no, u drugom dijelu knjige, naročito u završnim poglavljima, Cvitković je odličan, to je čisti znanstveni krešendo u kojemu se sjajno notira: "Još od 1991. godine jačali su procesi sakralizacije politike. Ponekad se nije mo- 
glo lučiti je li bosanskohercegovačka politika željela biti služavka konfesiji ili konfesija služavka takve politike. Božić i Bajram su postali gotovo politički događaji, a ne vjerski blagdani. Na sceni je bila nacionalna instrumentalizacija i rimokatoličanstva i pravoslavlja i islama. Napušten je vulgarni ateizam, a kao da su u društvu širom otvorena vrata vulgarnom teizmu." (str. 140-141)

Za mene, "vulgarni teizam" u neobičnoj i neuobičajenoj državnoj zajednici kao što je Bosna i Hercegovina predstavlja odsustvo bilo kakvog osjećaja za potrebe i vrijednosti Drugoga, a to znači da se Drugi samo i uvijek samo učitava u Naše, u Moje, kao da taj Drugi nema svoj autentični život i priznaje se samo kao On, kao odsutnost, a nikada kao Ti, kao prisutnost. A to je, kako primjećuje Ivan Cvitković, "specifičan vid nasilja nad ljudima” (str. 187).

Značajna vrijednost ovog rukopisa upravo je u toj mogućnosti da čitalac, građanin BiH koji se pokreće, ne na mržnju, već na ljubav i neinstrumentalizirani um, prepozna u sebi, u svome najbližem okruženju, u svojoj najbližoj zajednici importirane, ali i iznutra proizvedene strategije religijskog nacionalizma i pronađe snage da im se suprotstavi. Jer one dolaze i objavljuju se kao uvreda za Bosnu i njene ljude, bez obzira je li njihova polazna adresa Beograd, Zagreb ili Sarajevo. 